\title{
Magnetic resonance imaging as a means to assess the body growth and the gonad development of the oyster Crassostrea gigas
}

\author{
Philippe-Jacques Hatt ${ }^{1, \mathrm{a}}$, Armel Davenel ${ }^{2}$, Pierre-Antoine Eliat ${ }^{3}$ and Stéphane Quellec ${ }^{2}$ \\ 1 Ifremer, AGSAE, place du Séminaire, BP 7, 17137 L'Houmeau, France \\ 2 Cemagref, UR TERE, 17 avenue de Cucillé, CS 64427, 35044 Rennes, France \\ 3 Univ Rennes 1, PRISM-Villejean, Campus de Villejean, 3 avenue du Professeur Léon Bernard, 35043 Rennes, France
}

Received 3 November 2008; Accepted 11 June 2009

\begin{abstract}
To make a preliminary exploration of the possibilities and limits of magnetic resonance imaging (MRI) for assessing body growth and gonad development of the Pacific oyster, Crassostrea gigas, individual monitoring was conducted on diploid and triploid oysters in their second year, maintained from February to October in a pond on the French Atlantic coast. Magnetic resonance imaging was done on each oyster on five dates during the study period. From these images, variations in the volumes of the flesh, digestive gland-gonad and adductor muscle, and the surface of the gills were measured over time. Apart from the well known differences between diploids and triploids related to maturation of gametes, other original observations of assessing growth were made from these MRI measurements using a non-invasive technique. The standard error of mean dry flesh variation was lower than that found by other commonly used measurement methods. A negative correlation was established between the volume of the gametes spawned and the increase in dry flesh volume after spawning. Moreover, these variations were correlated with the chemical composition of the adductor muscle. All these observations and conclusions need to be confirmed by further observations on oysters of different sizes or grown in different environments.
\end{abstract}

Key words: MRI / Magnetic resonance imaging / Growth / Gonad development / Oyster / Crassostrea gigas

Résumé - Pour explorer les possibilités et les limites de l'imagerie en résonance magnétique (IRM) sur la croissance corporelle et le développement des gonades de l'huitre, Crassostrea gigas, des suivis individuels ont été effectués sur des huîtres diploïdes et triploïdes âgées de 2 ans, élevées en bassins de février à octobre sur les côtes Atlantiques françaises. L'IRM a été effectuée sur chaque huître, à cinq dates durant la période d'étude. Les variations de volume de la chair, de la glande digestive et du muscle adducteur, et de la surface des branchies ont ainsi été mesurées. A part les différences bien connues entre huîtres diploïdes et triploïdes liées à la maturation des gamètes, d'autres observations originales sur la croissance ont été effectuées à partir de ces mesures au moyen de l'IRM, technique non-invasive. L'erreur standard sur les variations de la chair sèche sont plus faibles que celles trouvées par les méthodes classiques. Une corrélation négative est observée entre le volume des gamètes émis et l'accroissement du volume de chair sèche après la ponte. De plus, ces variations sont corrélées avec la composition chimique du muscle adducteur. Ces observations et conclusions demandent à être confirmées par d'autres observations sur des huîtres de différentes tailles ou cultivées en conditions environnementales différentes.

\section{Introduction}

Standard methods for measuring the growth of the soft parts of juvenile and adult Crassostrea gigas or for evaluating the evolution of the gonad are destructive, as they involve the dissection of the flesh from the shell. Measurements and observations are commonly made on random samples from large groups of oysters, whereas individual monitoring is seldom done (Lango-Reynoso et al. 2000; Lango-Reynoso et al. 2006).

\footnotetext{
${ }^{a}$ Corresponding author: pjhatt@ifremer.fr
}

Variability within groups of oysters is wide due to their great capacity for adaptation to environmental conditions (food, temperature and salinity; Enriquez 2004). As a consequence, the spawning of a group of oysters is often observed to spread over some weeks, even months (Dinamani 1987; Shpigel 1989; Ruiz et al. 1992; Kang et al. 2000; Enriquez 2004; Dridi et al. 2007). Under certain environmental conditions, part of a stock can spawn a second time in the same year (Maurer and Borel 1986). It has been established that the "trade off" between growth and reproduction (Ernande et al. 2004) can be inherited (Degrémont et al. 2005, 2007), but no 
Table 1. Measurement timetable.

The number of oysters measured on each date is reported for each type of measurement and for each of the three groups $(2 \mathrm{~N}=$ diploid oysters, $3 \mathrm{NN}=$ triploid oysters produced by crossing tetraploids and diploids, $3 \mathrm{NC}=$ triploid oysters by treatment with cytochalasin-B of fertilised oocytes). Some oysters that were weighed went through MRI 0.2 T. Four of them went through MRI $4.7 \mathrm{~T}$ in each group.

\begin{tabular}{|c|c|c|c|c|c|c|c|c|c|}
\hline \multirow{3}{*}{ Date } & \multirow{2}{*}{\multicolumn{3}{|c|}{$\begin{array}{l}\text { Gross weight of the } \\
\text { whole oyster }\end{array}$}} & \multicolumn{3}{|c|}{ MRI $0.2 \mathrm{~T}$} & \multicolumn{3}{|c|}{ MRI 4.7 T } \\
\hline & & & & $\begin{array}{l}\text { Volv } \\
\text { dry } \\
\text { Gre } \\
\text { mus } \\
+\mathrm{m}\end{array}$ & $\begin{array}{l}\text { ll cav } \\
\text { ture } \\
\text { dduc } \\
\text { stive } \\
\text { nad }\end{array}$ & & $\begin{array}{l}\text { Volı } \\
\text { who } \\
\text { add } \\
\text { dige }\end{array}$ & $\begin{array}{l}\text { grey le } \\
\text { ody, } \\
\text { Iscle, } \\
\text { and }+\mathrm{n}\end{array}$ & gonad \\
\hline & $2 \mathrm{~N}$ & $\overline{3 N N}$ & $3 \mathrm{NC}$ & $2 \mathrm{~N}$ & $\overline{3 N N}$ & $3 \mathrm{NC}$ & $2 \mathrm{~N}$ & $3 \mathrm{NN}$ & $3 \mathrm{NC}$ \\
\hline Feb.-27 & 67 & 65 & 45 & 34 & 29 & 34 & 4 & 4 & 4 \\
\hline Apr.-11 & sam & & & sam & & & sam & & \\
\hline May-30 & sam & & & sam & & & sam & & \\
\hline July-11 & sam & & & sam & & & sam & & \\
\hline July -12 & $\begin{array}{l}10 \mathrm{i} \\
\text { who }\end{array}$ & $\begin{array}{l}\text { ls/gr } \\
\text { ody }\end{array}$ & & $\begin{array}{l}\text { diss } \\
\text { sex }\end{array}$ & $\begin{array}{l}\mathrm{ywt} \\
\text { mete }\end{array}$ & & & & \\
\hline Oct.-11 & 56 & 46 & 35 & 24 & 19 & 24 & sam & & \\
\hline
\end{tabular}

direct relation has been established between the parameters of growth and gametogenesis at the individual level; this relation could be useful for comparing variability within families or within a population.

The present study follows on from the work of Pouvreau et al. (2006a) and Davenel et al. (2006) on C. gigas. Its aim is to explore the possibilities and limits of magnetic resonance imaging (MRI) for assessing growth of the soft parts of individuals, and their gonad development. MRI has already shown some benefits for studying other aquatic invertebrates (Brouwer et al. 1992; Bock et al. 2001; Holliman et al. 2008; Ziegler et al. 2008).

The same individual oysters were measured and scanned five times, from end of February until mid-October 2007. These individuals were all offspring of the same group of females and came from one family of diploids and two families of triploids.

Individual monitoring was achieved by the analysis of successive sets of images from the same oysters, while the other methods commonly used can be qualified as "group monitoring" as they are based upon samples of different individuals at each measurement date. An important question of this study is therefore whether conclusions on the growth and sexual maturation of $C$. gigas would be different using an individuallybased MRI method rather than a more commonly used "group monitoring" method.

\section{Material and methods}

\subsection{Experimental oysters}

One group of triploids was obtained by crossing tetraploids and diploids (Guo et al. 1996); these were named 3NN. Another group of triploids was obtained by fertilisation of oocytes treated with cytochalasin $\mathrm{B}$, a technique which prevents the formation of the second polar body (Gérard et al. 1999); these were named $3 \mathrm{NC}$.

Diploids and $3 \mathrm{NC}$ triploids were bred from the same 2 females and 16 males, bought from an oyster farm in
La Tremblade. Parental age was estimated at around three years. Triploids in the $3 \mathrm{NN}$ group were bred from the same females as the others, but this time fertilised by tetraploid males from Ifremer stocks.

Reproduction, larvae and spat rearing were conducted in the Ifremer hatchery at La Tremblade; day of hatching: April $3^{\text {rd }}$ 2006. Larvae are reared in $30 \mathrm{~L}$ containers. The offspring from the different females were kept in a separate containers, according to the usual practice at the La Tremblade hatchery. Mortality was at a normal level, between 40 and $80 \%$, but higher in the $3 \mathrm{NC}$ group. Settlement occurred from April $24^{\text {th }}$ to May $4^{\text {th }}$, depending on group. Spat rearing was first done in the nursery part of the hatchery. Juveniles were then taken to the Ifremer nursery at Bouin for the continuation of the nursery phase from June $16^{\text {th }}$ to September $29^{\text {th }} 2006$. During this second period, survival varied from 19 to $80 \%$, and was higher for $2 \mathrm{~N}$ and $3 \mathrm{NN}$ than for $3 \mathrm{NC}$. Subsequently, the juveniles were tray-cultured from October 2006 to January 2007 at an oysterfarm in Ronce-les-Bains. Survival was above $95 \%$.

\subsection{Rearing conditions}

From February $7^{\text {th }}$ to October $16^{\text {th }} 2007$, the oysters are kept in an earth-bottomed pond at L'Houmeau-La Rochelle CNRS-Ifremer. The initial stock was 75 individuals in each group. Each oyster was individually labelled with a plastic tag stuck on its upper valve.

The surface of the pond was $4000 \mathrm{~m}^{2}$. Oysters were immersed at $20 \mathrm{~cm}$ height above the ground and 30 to $50 \mathrm{~cm}$ beneath the water surface. Water was renewed at high tide during every spring tide. The oysters were kept in plastic oyster trays, $0.5 \mathrm{~m}^{2}$ in size with a $10 \mathrm{~mm}$ mesh; 1 to $4 \mathrm{~kg}$ of oysters per tray. Temperature and salinity were measured each week using a multiparameter probe, and chlorophyll was measured by epifluorescence on water samples. To evaluate variation through the day and between water renewals, these parameters and dissolved oxygen were measured by means of in situ probes every 30 minutes.

The timing of the measurements is detailed in Table 1. 


\subsection{Gross weight}

Oysters were weighed on the same days as the MR imaging, in Rennes (France). Each oyster was cleaned of extraneous epifauna and mud, drained and weighed on a precision balance (accuracy $1 \mathrm{mg}$, gross weight). From February $27^{\text {th }}$ to July $11^{\text {th }}$, the gross weight of 177 oysters was measured and, on October $16^{\text {th }}$, gross weight of 137 was measured. The daily relative growth in terms of gross weight was defined as the increase of the logarithm of gross weight from one measurement to the next, divided by the number of days.

\subsection{Magnetic resonance imaging}

The same oysters were imaged five times: on February $27^{\text {th }}$, April $11^{\text {th }}$, May $30^{\text {th }}$, July $11^{\text {th }}$ and October $16^{\text {th }} 2007$, by means of MRI at 0.2 Tesla. Imaging was performed on 29 to 34 oysters from each group. On July $12^{\text {th }}, 10$ oysters of each group were opened and dissected to determine the sex of their gametes and to weigh their flesh. On the same day, four oysters from each group were MRI imaged at 4.7 Tesla, but none of these were opened.

\section{MR imaging at 0.2 Tesla}

MR images were captured with a $0.2 \mathrm{~T}$ Open Siemens system operating at $8.25 \mathrm{MHz}$ for ${ }^{1} \mathrm{H}$ and equipped with a "head" probe. Since the NMR relaxometry study showed that differentiation of tissues, on the basis of T2-weighted MRI images, was not very relevant, and in order to optimize the signal-to-noise ratio, a T1-weighted spin-echo sequence with an echo time $(T E)$ of $8-\mathrm{ms}$ value was chosen (band width, $B W=130 \mathrm{~Hz}$, plane resolution $<1 \mathrm{~mm}$ ).

The image matrix size was $128 \times 128$ voxels, with a field of view of $120 \times 120 \mathrm{~mm}^{2}$. Four to six oysters were scanned simultaneously, according to their size. On the basis of the results obtained by NMR relaxometry and following an optimisation made on some oysters while varying the repetition time $(T R)$, a sequence with a $T R=400 \mathrm{~ms}$ was systematically applied thereafter to obtain 18 to 23 consecutive transversal slices of $4 \mathrm{~mm}$ thickness per animal, with gradient-echo and spinecho sequences, respectively. To improve the signal-to-noise ratio, the number of accumulations was set at 15 . The acquisition time was 12.5 min for each group of four to six oysters. The resulting images were orthogonal to the anterior-posterior axis.

\section{MR imaging at 4.7 Tesla}

MR images were acquired at $4.7 \mathrm{~T}$ on a horizontal magnet, Biospec 47/40, Bruker-Biospin, equipped with a BG-12 gradient insert and a volume coil. Due to a higher magnetic field, T2 contrast was more relevant and thus complementary to images obtained at $0.2 \mathrm{~T}$. A multi-slice multi-echo (MSME) sequence with a repetition time $T R=2500 \mathrm{~ms}$ and an echo time $T E=40 \mathrm{~ms}$ (band width, $B W=50 \mathrm{kHz}$ ). To improve the signal-to-noise ratio, the number of accumulations was set to 2. As the oysters grew during the eight month experimental period, the field of view, acquisition matrix and the number of slices had to be adapted in order to keep the in-plane resolution constant. When the number of slices was too large for the $T R$, acquisition was performed in two steps in order to image the whole animal with the same $T R$. Slice thickness was $1 \mathrm{~mm}$ every $1.25 \mathrm{~mm}$. The two different acquisition configurations were:

$\begin{array}{cc}\text { configuration matrix } & \text { field of view } \\ 1128 \times 128 & 25.6 \mathrm{~mm} \times 25.6 \mathrm{~mm} \\ 2320 \times 160 & 64.0 \mathrm{~mm} \times 32.0 \mathrm{~mm} \\ & \\ \text { in-plane resolution } & \text { acquisition time } \\ 200 \mu \mathrm{m} \times 200 \mu \mathrm{m} & 10 \mathrm{~min} 40 \mathrm{~s} \\ 200 \mu \mathrm{m} \times 200 \mu \mathrm{m} & 13 \mathrm{~min} 20 \mathrm{~s}\end{array}$

The images were orthogonal to the anterior-posterior axis ("orthogonal images").

\subsection{Analyses of MR images}

All the images were analysed using Image J software tools (National Institute of Health, USA).

\section{Anatomic evolution from MR images at $0.2 \mathrm{~T}$}

The volumes of the shell cavity and flesh were estimated on the $0.2 \mathrm{~T}$ MRI, using the relation worked out by Davenel et al. (2006). A voxel was taken as an element of the dry flesh, if its grey level was above 52. For each oyster, the volume of the dry flesh corresponds to the volume of one voxel multiplied by the number of voxels with the same level of grey. The volume of one voxel is $3.52 \mathrm{~mm}^{3}$. From February $27^{\text {th }}$ to July $11^{\text {th }}$, dry flesh volume was measured on 97 oysters among the 177 oysters weighed. On October $16^{\text {th }}$ there were only 67 oysters, as 30 had been dissected on July $12^{\text {th }}$ (10 from each group). To evaluate the relation between the volume of dry flesh and its weight on this date, ten oysters of each group were dissected, the entire soft parts were then lyophilised and weighed separately for each oyster.

\section{Anatomic evolution from MR images at $4.7 T$}

On each 4.7 T MRI, the water in the shell cavity and some organs could be clearly distinguished (gills, adductor muscle, heart cavity, digestive duct, labial palps, digestive gland and mature gonad). Outside of the period of full gamete maturity, the gonad tissues were not clearly distinguishable from the digestive gland tissues. The digestive gland and the gonad were therefore taken together as a whole when analysing the pictures. The volume of an organ was defined as the total number of voxels attributed to this organ for all the images, multiplied by the voxel volume.

The 4.7 T MRI were more detailed than the $0.2 \mathrm{~T} \mathrm{MRI,} \mathrm{as}$ the volume of one voxel is $0.05 \mathrm{~mm}^{3}$.

\section{Measurement of volume variations}

The daily relative variation in the volume of the whole soft body or of any organ is the difference between the logarithmic values from one measurement to the next, divided by the number of days between the measurement dates. 


\section{Observation of gonad maturation by MR images at $0.2 \mathrm{~T}$}

The assessment of the maturation of a gonad is based upon the analysis of the grey level of the images (Davenel et al. 2006). These authors took the adductor muscle as a reference to evaluate the maturity of the gonad: its grey level is constant among oysters and within this organ.

\section{Evolution of the grey level of the adductor muscle on MR images at $0.2 \mathrm{~T}$}

The adductor muscle could clearly be distinguished on one to three images, according to oyster size. The number of voxels and their grey level were measured on each of these images.

\section{Evolution of grey level and volume of the digestive gland and gonad on MR images at $0.2 \mathrm{~T}$}

As on 4.7 T MRI, it was difficult to separate the gonad from the digestive gland, except during the period of full gamete maturity. The digestive gland and gonad were considered together when analysing these images. The number of voxels making up the image of this gland and their grey level were measured on the same oysters as for the adductor muscle. On May $30^{\text {th }}$, it was reasonable to assume that the gonads of the majority of the diploid oysters were mature. From the comparison of the 4.7 T MR images of diploids on successive dates, it was possible to see which areas of the gonads had reached maturity. The number of voxels of these areas and their grey level were measured and used as a reference for analysis of the $0.2 \mathrm{~T}$ MR images.

A "maturity index" was computed as the ratio of the volume of the mature gonad to the volume of the flesh.

The sex of the gametes was determined by microscopic observation of a biopsy from the gonad of the oysters dissected on July $12^{\text {th }}$.

\subsection{Statistical analysis}

All the methods are from Sokal and Rohlf (1969). Regression lines were compared by means of an analysis of covariance. Values of the parameters on each date were compared among the three groups by use of an a priori comparison of means and groups of means in a single classification Model I analysis of variance. When there was a significant difference, an a posteriori analysis was done to detect which groups were different.

For the same parameters, the values of daily relative variations were compared among the three groups and among the four successive periods of time using a priori comparison of means and groups with a two-way analysis of variance. When there was a significant difference, an a posteriori analysis was done to detect which groups or which periods of times were different.

The homogeneity of variation in each parameter among individuals within a single group, through the seasons, was analysed using the Kendall rank test: the ranks of the oysters according to the value of the variation of the parameter over one
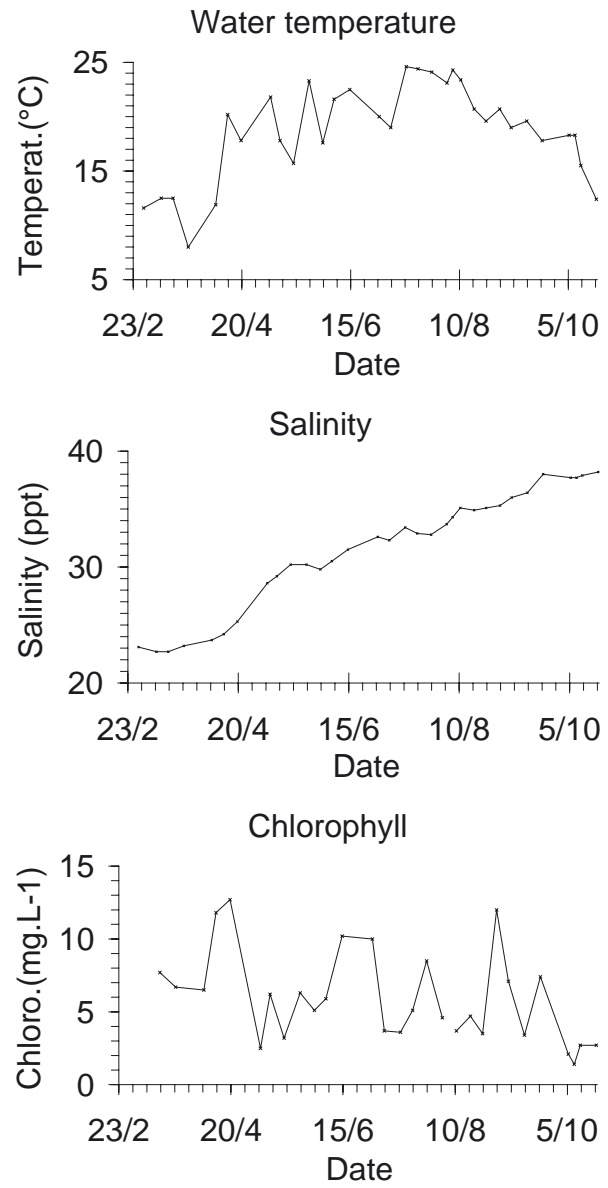

Fig. 1. Temperature, salinity and chlorophyll in the oyster rearing pond.

period of time was compared with the ranks for the next. Another method was also used, inclusive of the four successive periods of time from February $27^{\text {th }}$ to October $11^{\text {th }}$ : for each oyster, the four values of the variations of a parameter were computed, then the $\chi^{2}$ distance was computed between these values and the four median values for all the oysters of the same group. This distance was compared with the critical value of $\chi^{2}$ for 3 degrees of freedom and at 0.05 level $(p=7.85)$, with the values for 67 oysters measured (24 diploids, 19 3NN triploids and $243 \mathrm{NC}$ triploids).

\section{Results}

The values of the three environmental parameters are shown (Fig. 1). Daily or weekly variation was never more than $4{ }^{\circ} \mathrm{C}$ for temperature and $5 \mathrm{~g} \mathrm{~L}^{-1}$ for salinity. Chlorophyll concentration was high from March to September; it peaked following water renewal at spring tides and was very low in October, after there had been heavy rain. Dissolved oxygen concentration was generally above $6 \mathrm{mg} \mathrm{L}^{-1}$ and the lowest concentration measured was $2.5 \mathrm{mg} \mathrm{L}^{-1}$.

\subsection{Dry flesh volume and dry flesh weight}

From the measurements made on 30 oysters on July $12^{\text {th }}$, a highly significant regression line can be drawn between the 

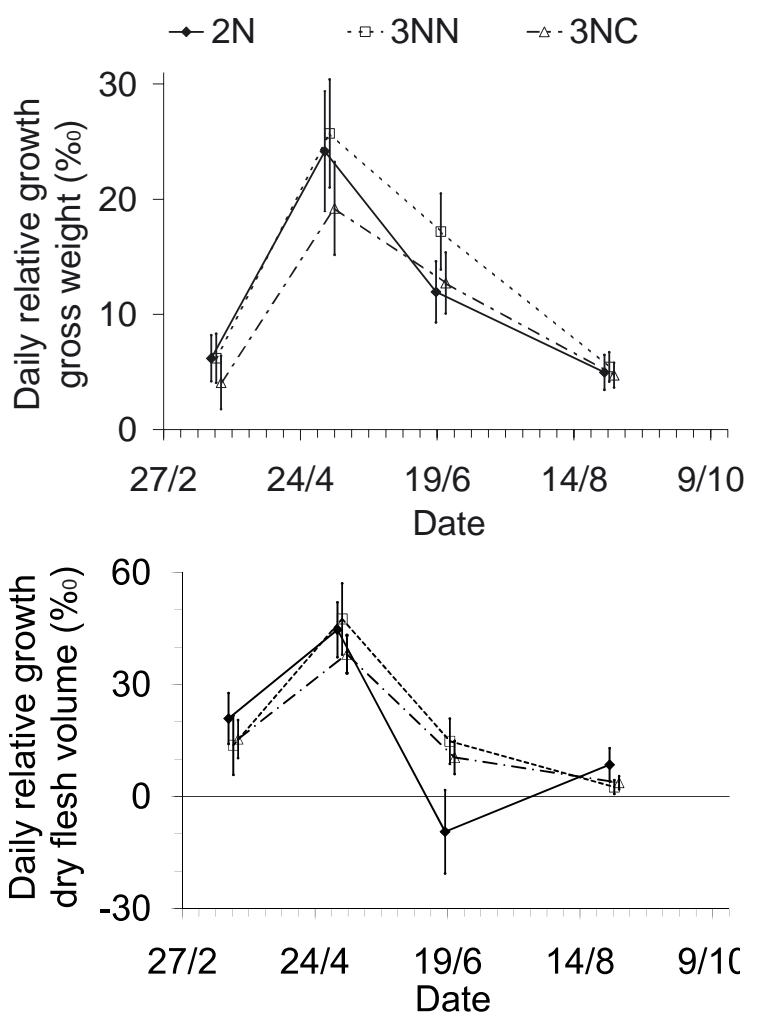

Fig. 2. (a) Daily relative growth in terms of gross weight according to time. The values of daily relative growth for each group are plotted against time. The vertical bars represent twice the standard deviation for each point. (b) Daily relative growth of the dry flesh volume, by 0.2 T MRI, according to time.

dry flesh weight $(D F W, \mathrm{~g})$, and the number of voxels with a grey level higher than 52 on the $0.2 \mathrm{~T}$ MRI (noted GL53):

$$
D F W=(0.06 \pm 0.33)+(0.97 \pm 0.09) G L 53 .
$$

It was not significantly different from the regression line established by Davenel et al. (2006).

\subsection{Body growth}

The daily relative growth in terms of gross weight (Fig. 2a) and dry flesh volume (Fig. 2b) show similar evolution, except between May $30^{\text {th }}$ and July $11^{\text {th }}$ : gross weight increased while dry flesh volume of the majority of diploid oysters decreased. From the 4.7 T MRI of the diploids it can be concluded that gametes are spawned during this period of time, as spawning is commonly observed at this period of the year when temperature rises above $19{ }^{\circ} \mathrm{C}$ (Chavez-Villalba et al. 2002; Lango-Reynoso et al. 2006; Pouvreau et al. 2006b). This was confirmed by direct observation of the oysters dissected on July $12^{\text {th }}$.

According to the variance analysis of daily relative growth of the gross weight and dry flesh volume, differences among time periods in the three oyster groups are very highly significant. An a posteriori analysis showed a significant difference between the $3 \mathrm{NN}$ triploids and each of the two other groups: diploids and $3 \mathrm{NC}$ triploids. There is no significant difference between these two groups, for either of the two parameters. Over the entire experimental period, the growth of the $3 \mathrm{NN}$ triploids was significantly higher.

We examined whether individual growth was homogeneous within each group. When comparing the rank of the oysters according to their growth over one period of time to their rank during the next (Kendall rank test), the results depended on the parameter used to measure this growth in terms of:

- Gross weight, there was a high probability that the rank remained the same, except for the $3 \mathrm{NC}$ triploids from July until October,

- Dry flesh volume, the probability of keeping the same rank was not significant for any group at any time period.

Similar results were obtained using the $\chi^{2}$ distance between the individual growth values and the median growth values (Table 2) in terms of:

- Gross weight, no single oyster was higher than the critical value, i.e. no oyster,

- Dry flesh volume, 18 oysters out of 67 have growth significantly different from the median (nine diploids, six 3NN triploids, and three $3 \mathrm{NC}$ triploids).

Oyster growth was homogeneous and synchronous when the whole body was considered and heterogeneous and asynchronous when considering the flesh. The $\chi^{2}$ method indicated that the diploids were less homogeneous than the triploids.

\subsection{Comparing results of individual growth monitoring with the evaluations made by usual methods}

For gross weight and dry flesh volume, the growth values were the same when computed as (1) the growth of the average value from one measurement date to the next, and (2) the mean individual growth. The standard error was always lower with the second method (Table 3): growth variability was overestimated by the more commonly used method. This growth overestimation was larger in terms of gross weight than in terms of dry flesh volume.

Evolution in volume of flesh, adductor muscle and digestive gland-gonad with MR images at $4.7 \mathrm{~T}$

The volumes of flesh, adductor muscle and digestive gland-gonad were used to obtain the daily relative variation of each organ for each period of time. Variance analysis showed a highly significant difference among periods of time, but no significant difference among the groups for any of the three parameters. The ranking of the oysters according to each parameter was significantly modified from one period of time to the next (Kendall rank test) whatever successive periods were compared: daily variations were shown to be different by this method, although this was not detected by the variance analysis.

\section{Evolution of the grey level of the adductor muscle in $M R$ images at $0.2 T$}

Grey level of the adductor muscle generally increased or remained stable (Fig. 3a), except a decrease in June/July for 
Table 2. Standard error of the daily relative growth in terms of gross weight and dry flesh volume, computed from the average value on each measurement date ("growth of the average") and from the average value of the individual growth measurements ("average of the growths"). This table gives the ratio of the value of the standard error to the value of the growth for each period of time, for each group and for each method of computing the growth.

\begin{tabular}{|c|c|c|c|c|c|c|c|}
\hline & \multirow[b]{2}{*}{ Period of time } & \multicolumn{2}{|c|}{ Diploids } & \multicolumn{2}{|c|}{ 3NN Triploids } & \multicolumn{2}{|c|}{ 3NC Triploids } \\
\hline & & $\begin{array}{l}\text { Growth } \\
\text { of the } \\
\text { average }\end{array}$ & $\begin{array}{l}\text { Average } \\
\text { of the } \\
\text { growths }\end{array}$ & $\begin{array}{l}\text { Growth } \\
\text { of the } \\
\text { average }\end{array}$ & $\begin{array}{l}\text { Average } \\
\text { of the } \\
\text { growths }\end{array}$ & $\begin{array}{l}\text { Growth } \\
\text { of the } \\
\text { average }\end{array}$ & $\begin{array}{l}\text { Average } \\
\text { of the } \\
\text { growths }\end{array}$ \\
\hline Daily & Feb. 27-Apr. 11 & $47 \%$ & $6 \%$ & $34 \%$ & $8 \%$ & $61 \%$ & $7 \%$ \\
\hline relative & Apr. 11-May 30 & $9 \%$ & $4 \%$ & $8 \%$ & $4 \%$ & $11 \%$ & $5 \%$ \\
\hline growth of & May 30-July 11 & $17 \%$ & $4 \%$ & $10 \%$ & $3 \%$ & $14 \%$ & $4 \%$ \\
\hline gross weight & July 11-Oct. 16 & $18 \%$ & $7 \%$ & $13 \%$ & $3 \%$ & $14 \%$ & $4 \%$ \\
\hline Daily & Feb. 27-Apr. 11 & $18 \%$ & $7 \%$ & $22 \%$ & $9 \%$ & $17 \%$ & $5 \%$ \\
\hline relative & Apr. 11-May 30 & $6 \%$ & $3 \%$ & $5 \%$ & $5 \%$ & $6 \%$ & $3 \%$ \\
\hline growth of & May 30-July 11 & $30 \%$ & $24 \%$ & $13 \%$ & $8 \%$ & $18 \%$ & $8 \%$ \\
\hline dry flesh volume & July 11-Oct. 16 & $15 \%$ & $10 \%$ & $29 \%$ & $17 \%$ & $23 \%$ & $10 \%$ \\
\hline
\end{tabular}

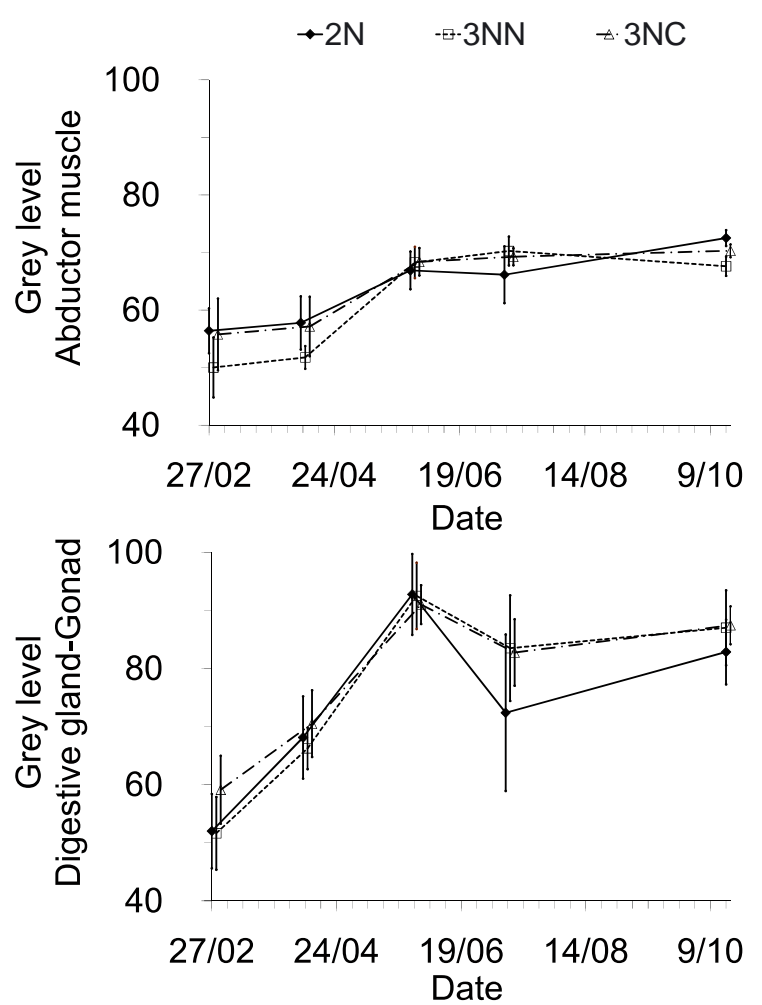

Fig. 3. (a) Grey level of the adductor muscle, by $0.2 \mathrm{~T}$ MRI, according to time. The values of the grey level for each group are plotted against time. The vertical bars represent twice the standard deviation for each point. (b) Grey level of the digestive gland-gonad, by $0.2 \mathrm{~T}$ MRI, according to time.

some diploids. Variance analysis of adductor muscle grey level values showed a significant difference among the groups. Temporal variations in this parameter were significantly different among time periods, but there was no difference among the groups. An a posteriori analysis only showed a significant increase for the period from April $11^{\text {th }}$ to May $30^{\text {th }}$.
Evolution of the grey level of the digestive gland-gonad in MR imaging at $0.2 T$

Grey level of the digestive gland - gonad increased from February $27^{\text {th }}$ to May $30^{\text {th }}$ and from July $11^{\text {th }}$ to October $16^{\text {th }}$ after a decrease from May $30^{\text {th }}$ to July $11^{\text {th }}$ in the majority of the oysters (Fig. 3b). These variations were greater than for the adductor muscle. Variance analyses were performed on the grey level values and the values of their variations between two successive measurements, giving similar results to those with the adductor muscle. An a posteriori analysis of the grey levels showed there was only a significant difference between the diploids and the triploids on July $11^{\text {th }}$. There was a significant difference between the diploids and the triploids between May $30^{\text {th }}$ and July $11^{\text {th }}$, but not between July $11^{\text {th }}$ and October $16^{\text {th }}$. Thus, diploids and triploids had a similar evolution in composition of the digestive gland-gonad until the diploids spawned.

On each measurement date, there was a significant correlation between the individual values of adductor muscle and digestive gland-gonad grey level, except on October $16^{\text {th }}$. Moreover, on each date of measurement, the rank of the oysters based on muscle grey level was not significantly different from their rank based on digestive gland-gonad grey level, except on October $16^{\text {th }}$. The two grey levels can, therefore, be considered to be proportional, except on October $16^{\text {th }}$.

On May $30^{\text {th }}$, on all the images of diploids analysed, the grey level of the areas viewed as "mature gametes" was always higher than 75 . On the same oysters, less than $10 \%$ of the voxels attributed to the adductor muscle had a grey level higher than 75 while all other parts of the flesh had lower grey levels. It was assumed that all the voxels with a grey level higher than 75 could be attributed to mature gametes on May $30^{\text {th }}$.

On October $16^{\text {th }}$, comparison of the $4.7 \mathrm{~T}$ and the $0.2 \mathrm{~T}$ MRI showed that all the voxels with a grey level higher than 75 on the $0.2 \mathrm{~T}$ MRI were in the same position in the digestive gland-gonad as the mature gametes were on May $30^{\text {th }}$ and July $11^{\text {th }}$. Even though there were no more mature gametes left on October $16^{\text {th }}$, these voxels were labelled "mature gonad-like material".

All the voxels with a grey level above 75 were considered as parts of a mature gonad or "mature gonad-like material". Thus, the "maturity index" is the proportion of voxels with a 


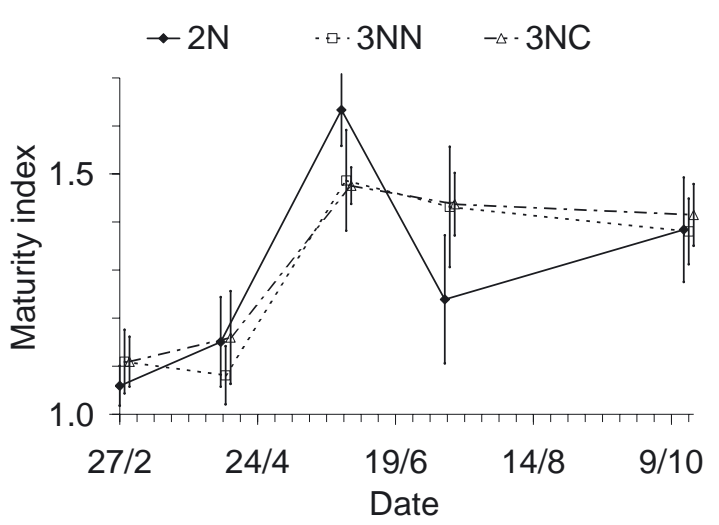

Fig. 4. Maturity index by means of $0.2 \mathrm{~T}$ MRI, according to time The values of the maturity index for each group are plotted against time. The vertical bars represent twice the standard deviation for each point.

grey level higher than 75 out of the total number of voxels with a grey level higher than 52 .

On July $12^{\text {th }}$, from microscope examination of 10 oysters of each group, it was concluded that all the oysters had gametes. The majority of the diploids had released their gametes by this date and the gametes of the triploids were not fully mature.

The rank of the oysters based on the grey level of their digestive gland - gonad changed significantly from one date to the next (Kendall rank test), whatever the group or the period of time. The oysters were asynchronous in their evolution of the digestive gland-gonad.

\section{Evolution of the volume of the mature gonads by means of MR images at $0.2 \mathrm{~T}$}

The "maturity index" increased for all three groups until May $30^{\text {th }}$, and then decreased sharply for the majority of diploids, while the variations were lower in the triploids (Fig. 4). Analysis of variance indicated that the differences among the groups were highly significant, and a posteriori analysis showed that the difference was significant between the $3 \mathrm{NC}$ triploids and the two other groups, but not between the diploids and the $3 \mathrm{NN}$ triploids.

Evolution of the "maturity index" was measured by variation of the number of voxels with a grey level higher than 75 . The $\chi^{2}$ distance between the individual variation values and the median variation values exceed the significance limit for all diploids, for 24 out of 24 diploids, 17 out of 19 3NN triploids and 18 out of $243 \mathrm{NC}$ triploids. According to the "maturity index", the evolution of every diploid and of the great majority of the triploids was different from the mean group.

Daily relative variations of the the dry flesh and voxel volumes with a grey level $>75$ (mature gonad or "mature gonad-like material") on MR images at $0.2 \mathrm{~T}$

Comparing individual daily variations in the dry flesh volume from one period of time to the next, there was no significant correlation for the early period (February $27^{\text {th }}$ to April $11^{\text {th }}$, April $11^{\text {th }}$ to May $30^{\text {th }}$ and May $30^{\text {th }}$ to July $\left.11^{\text {th }}\right)$, but

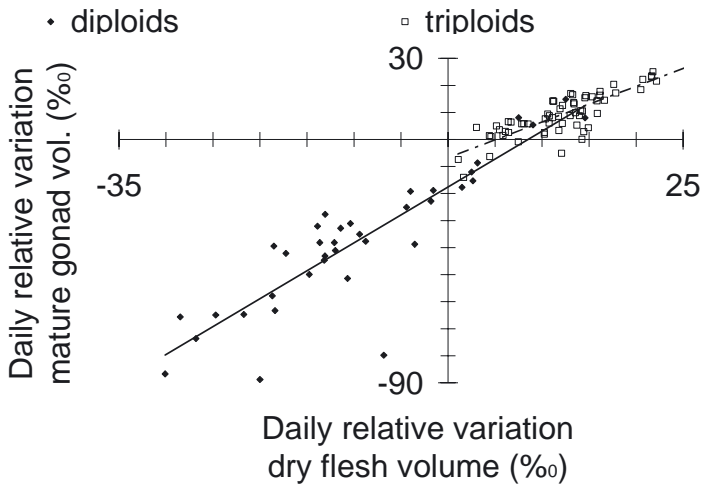

Fig. 5. Daily relative variation in the volume of the mature gonad or of the "mature gonad-like material" in relation to the daily relative variation of the dry flesh volume by $0.2 \mathrm{~T}$ MRI from May $30^{\text {th }}$ to July $11^{\text {th }}$ The value of the daily relative variation of mature gonad volume is plotted for each oyster against the value of the daily relative variation of dry flesh volume. Regression lines are plotted separately for diploid and triploid groups.

a significant correlation for the last two periods of time (May $30^{\text {th }}$ to July $11^{\text {th }}$ and July $11^{\text {th }}$ to October $16^{\text {th }}$ ). To make a more detailed analysis of these last two periods of time, a comparison was made between the rank of the oysters according to the decrease in dry flesh volume from May $30^{\text {th }}$ to July $11^{\text {th }}$ and their rank according to its increase from July $11^{\text {th }}$ to October $16^{\text {th }}$ (Kendall Rank test). The ranks of the diploids were not significantly different $(p<0.01)$ : the diploids that had the greatest decrease in the first period of time had the highest increase in the second period of time, and vice-versa. This pattern was not observed in the $3 \mathrm{NN}$ or $3 \mathrm{NC}$ triploids $(p>0.05)$.

The number of voxels with a grey level above 75 was very low or low for the majority of the oysters on February $27^{\text {th }}$ and April $11^{\text {th }}$, and was significant only on May $30^{\text {th }}$. For the subsequent data treatment the two periods of time between February $27^{\text {th }}$ and May $30^{\text {th }}$ were considered as a single time period.

There is a significant correlation between the daily relative variation of dry flesh volume and the daily relative variation in the volume of voxels with a grey level higher than 75 (mature gonad or "mature gonad-like material") for each period of time and for each group. A regression line can be drawn for each period of time and for each group. All the values of the slope of the regression lines are higher than 1 . From May $30^{\text {th }}$ to July $11^{\text {th }}$ in the majority of the diploids, the dry flesh volume and mature gonad volume both decreased (Fig. 5). Spawning occurred in these diploids during this same period of time. Some other diploids may have spawned after July $11^{\text {th }}$, but image was not available for August or September.

During the two periods of time from May $30^{\text {th }}$ to October $16^{\text {th }}$, a comparison was made between the rank of the oysters according to (1) the summed decreases in the volume of the dry flesh and mature gonad between May $30^{\text {th }}$ and July $11^{\text {th }}$ and (2) the summed increases in the same volumes between July $11^{\text {th }}$ and October $16^{\text {th }}$ (Kendall rank test). For the diploids and the $3 \mathrm{NN}$ triploids, the ranks were not significantly different $(p<0.01)$ : the oysters that had the highest decrease during the first time period showed the highest increase during the second period of time, and vice-versa. This was not observed in the 
$3 \mathrm{NC}$ triploids $(p>0.05)$. This pattern is slightly different from what is observed with the dry flesh volume alone.

A comparison between the variation of the grey level of the adductor muscle and the variation of the volume of the mature gonad and of the "mature gonad-like material" (Kruskall rank test) showed that the ranks of the oysters did not differ $(p<0.01)$. As the grey level of the adductor muscle is related to its biochemical composition, this is an indication that the evolution of the composition of the adductor muscle according to the season is similar to the evolution of the volume of the gonad.

\section{Discussion}

\subsection{Growth}

Growth was analysed in terms of gross weight and dry flesh by three different methods. When growth was computed from individual gross weight, the growth curve of each oyster was not significantly different from the median growth curve. However, when growth was computed from individual dry flesh volume, the growth curve of each oyster was significantly different from the median growth curve.

Secondly, a comparison was made between the standard deviations of mean growth and those of the means of individual growth. Average growth is commonly computed from the mean values of a parameter (gross weight or dry flesh volume) on successive dates. When using MRI, average growth was computed from the growth measurements made on individuals. For each of the three groups of oysters and each parameter, both values by both methods are equivalent: individual monitoring gives the same result as the commonly used group method. The standard deviations from the individual monitoring were smaller than those based on the commonly used method. This can be attributed to the initial difference among individuals, which persists. This difference among standard deviations is greater for growth based on gross weight than for growth based on dry flesh volume.

Thirdly, we examined whether the rank of the oysters according to the growth values was stable through time. The rank of the oysters according to the growth in gross weight did not change significantly in the four periods of time from February $27^{\text {th }}$ to October $16^{\text {th }}$, while rank according to the growth of dry flesh volume was modified in every period of time.

These three observations are clear indications that the growth in terms of gross weight is quite homogenous within a group of oysters and the growth in terms of dry flesh is quite heterogeneous. Such heterogeneity is also noticeable in the growth of the adductor muscle and the digestive gland-gonad.

\subsection{Evolution of the maturity of the gonads}

Gonad maturity can be assessed by the grey level of the digestive gland-gonad. This increased sharply from April $11^{\text {th }}$ to May $30^{\text {th }}$ when growth was highest (gross weight, dry flesh, and digestive gland-gonad).

The grey level of the digestive gland-gonad on $0.2 \mathrm{~T}$ MRI and 4.7 T MRI showed the same evolution for the three oyster groups from February $27^{\text {th }}$ to May $30^{\text {th }}$. Under the assumption that grey level is related to biochemical composition of the whole digestive gland-gonad, this is an indication that the evolution of this organ is similar in diploids and triploids. This is in accordance with previous observations on the lipid content of the digestive gland-gonad in oysters from an oyster farm in Marennes-Oléron (De La Parra et al. 2005) and in C. plicatula oysters from an eastern coastal bay of China (Li et al. 2006): there is an accumulation of triacylglycerols, phospholipids and cholesterol at the onset of vitellogenesis and during gonad maturation, then a sharp decrease after spawning.

On July $11^{\text {th }}$, there was a marked difference between most of the diploids and most of the triploids. For the majority of diploids, the decrease in the grey level was related to the release of gametes. The decrease observed in some triploids is lower than that in diploids and can be related to the resorption of the gametes (Pouvreau et al. 2006b).

From the $0.2 \mathrm{~T}$ MRI, the diploids that spawned the most were seen to be those which subsequently grew the most. While the triploids had lower growth from July $11^{\text {th }}$ to October $16^{\text {th }}$ than from April $11^{\text {th }}$ to May $30^{\text {th }}$, the majority of the diploids had similar growth during these two periods of time. Observations made on oyster farms can be similar, e.g. De La Parra et al. (2005) in the bay of Marennes-Oléron in 1997, or different, e.g. Deslous-Paoli and Héral (1988), in the same region in 1979, and Maurer and Borel (1986) in the Bay of Arcachon. Food could have been a limiting factor during these previous studies, while, in the present experiment, it was not.

As the adductor muscle has been considered a possible reference for assessing the maturity of the gametes (Davenel et al. 2006), this organ was examined closely. The individual variations in the grey level of the muscle are in proportion and synchronised with the variations in volume of the mature gonad. The grey level is supposed to be related to lipid content, but the only available data on chemical composition of this muscle according to the season (Berthelin et al. 2000) are not in accordance with this hypothesis. In this previous study, the lipid content of the adductor muscle increased slightly from February until mid-August, then increased sharply in September, one month after spawning, and then decreased; the carbohydrate content varied slightly throughout the year, without any marked peak. Under our conditions, the grey level of the adductor muscles shows the highest increase before the majority of the diploids spawn and no variation is seen afterwards.

\section{Conclusion}

Individual monitoring by MRI gives the same results as commonly used "group monitoring" methods, when measuring oyster growth in terms of gross weight or dry flesh. With both methods there was a significant difference among diploids, 3NC triploids and 3NN triploids, and among periods of time through the year. However, individual monitoring revealed that the growth of the flesh is heterogeneous and asynchronous within each group, while the growth of the gross weight is both homogeneous and synchronous.

One conclusion of Pouvreau et al. (2006a), and Davenel et al. (2006) was confirmed with added precision: 0.2 T MRI makes it possible to quantify the maturation of the gonad and the volume of the gametes and 4.7 T MRI makes it possible to make an accurate analysis of the evolution of the volume of 
some organs (digestive gland and gonad, gills, digestive tract, cardiac cavity, labial palps, etc.).

When measuring the evolution of the volume of mature gonad and dry flesh, MRI reveals one important difference between diploids and triploids: after spawning, a majority of the diploids have a larger increase of flesh volume than the triploids, which do not spawn. Among diploids, this increase is proportional to the volume of gametes released and variations in muscle biochemical composition. This last point needs to be confirmed by measurements of the chemical composition of the muscle after MRI on the same oysters.

This present study is therefore a first step reporting the most significant MRI observations, although observations and measures are possible on other organs. This study was based upon a small number of oysters kept in a pond where phytoplankton density was high during most of the measuring period. Growth is relatively high and the condition index generally good. The rearing conditions are favourable and not relevant from a selective point of view. The next step will be to test the method in a selective environment, for instance with limited food resources.

\section{References}

Berthelin C., Kellner K., Mathieu M., 2000, Storage metabolism in the Pacific oyster (Crassostrea gigas) in relation to summer mortalities and reproductive cycle (West Coast of France). Comp. Biochem. Physiol. Part B: Biochem. Mol. Biol. 125, 359-369.

Bock C., Frederich M., Wittig R.M., Portner H.O., 2001, Simultaneous observations of haemolymph flow and ventilation in marine spider crabs at different temperatures: a flow weighted MRI study. Magn. Reson. Imaging 19, 1113-1124.

Brouwer M., Engel D.W., Bonaventura A.J., Johnson G.A., 1992, In vivo magnetic-resonance-imaging of the blue-crab, Callinectes sapidus - effect of cadmium accumulation in tissues on proton relaxation properties. J. Exp. Zool. 263, 32-40.

Chavez-Villalba J., Pommier J., Andriamiseza J., Pouvreau S., Barret J., Cochard J.-C., Le Pennec M., 2002, Broodstock conditioning of the oyster Crassostrea gigas: origin and temperature effect. Aquaculture 214, 115-130.

Davenel A., Quellec S., Pouvreau S., 2006, Noninvasive characterization of gonad maturation and determination of the sex of Pacific oysters by MRI. Magn. Reson. Imaging 24, 1103-1110.

De La Parra A.M., Garcia O., San Juan F., 2005, Seasonal variations on the biochemical composition and lipid classes of the gonadal and storage tissues of Crassostrea gigas (Thunberg, 1794) in relation to the gametogenic cycle. J. Shellfish Res. 24, 457-467.

Degrémont L., Bedier E., Soletchnik P., Ropert M., Huvet A., Moal J., Samain J.-F., Boudry P., 2005, Relative importance of family, site, and field placement timing on survival, growth, and yield of hatchery-produced Pacific oyster spat (Crassostrea gigas). Aquaculture 249, 213-229.

Degrémont L., Ernande B., Bedier E., Boudry P., 2007, Summer mortality of hatchery-produced Pacific oyster spat (Crassostrea gigas). I. Estimation of genetic parameters for survival and growth. Aquaculture 262, 41-53.

Deslous-Paoli J.-M., Héral M., 1988, Composition biochimique et teneur énergétique de Crassostrea gigas (Thunberg) cultivée dans le bassin de Marennes-Oléron. Aquat. Living Resour. 1, 239-249.
Dinamani P., 1987, Gametogenic patterns in populations of Pacific oyster, Crassostrea gigas, in Northland, New Zealand. Aquaculture 64, 65-76.

Dridi S., Romdhane M.S., Elcafsi M., 2007, Seasonal variation in weight and biochemical composition of the Pacific oyster, Crassostrea gigas in relation to the gametogenic cycle and environmental conditions of the Bizert lagoon, Tunisia. Aquaculture 263, 238-248.

Enriquez D.M., 2004, Variabilité et bioénergétique de la reproduction chez l'huître creuse Crassostrea gigas. $\mathrm{PhD}$, Océanologie biologique, Brest, Université de Bretagne Occidentale.

Ernande B., Boudry P., Clobert J., Haure J., 2004, Plasticity in resource allocation based life history traits in the Pacific oyster, Crassostrea gigas. I. Spatial variation in food abundance. J. Evol. Biol. 17, 342-56.

Gérard A., Ledu C., Phélipot P., Naciri-Graven Y., 1999, The induction of MI and MII triploids in the Pacific oyster Crassostrea gigas with 6-DMAP or CB. Aquaculture 174, 229-242.

Guo X., DeBrosse G., Allen S.K. Jr., 1996, All-triploid Pacific oysters Crassostrea gigas (Thunberg) produced by mating tetraploids and diploids. Aquaculture 142, 149-161.

Holliman F.M., Davis D, Bogan A.E., Kwak T.J., Cope W.G., Levine J.F., 2008, Magnetic resonance imaging of live freshwater mussels (Unionidae). Invertebr. Biol. 127, 396-402.

Kang C.K., Park M.S., Lee P.Y., Choi W.J., Lee W.C., 2000, Seasonal variations in condition, reproductive activity, and biochemical composition of the Pacific oyster, Crassostrea gigas (Thunberg) in suspended culture in two coastal bays of Korea. J. Shellfish Res. 19, 771-778.

Lango-Reynoso F., Chavez-Villalba J., Cochard J.-C., Le Pennec M., 2000 , Oocyte size, a means to evaluate the gametogenic development of the Pacific oyster, Crassostrea gigas (Thunberg). Aquaculture 190, 183-199.

Lango-Reynoso F., Chavez-Villaba J., Le Pennec M., 2006, Reproductive patterns of the Pacific oyster Crassostrea gigas in France. Invertebr. Reprod. Dev. 49, 41-50.

Li Q., Liu W.G., Shirasu K., Chen W.M., Jiang S.X., 2006, Reproductive cycle and biochemical composition of the the oyster Crassostrea plicatula Gmelin in an eastern coastal bay of China. Aquaculture 261, 752-759.

Maurer D., Borel M., 1986, Croissance, engraissement et cycle sexuel de Crassostrea gigas dans le basin d'Arcachon : comparaison des huîtres âgées de 1 et 2 ans. Haliotis 15, 125-134.

Pouvreau S., Rambeau M., Cochard J.C., Robert R., 2006, Investigation of marine bivalve morphology by in vivo MR imaging: First anatomical results of a promising technique. Aquaculture 259, 415-423.

Pouvreau S., Bourles Y., Lefebvre S., Gangnery A., Alunno-Bruscia M., 2006, Application of a dynamic energy budget model to the Pacific oyster, Crassostrea gigas, reared under various environmental conditions. J. Sea Res. 56, 156.

Ruiz C., Abad M., Sedan F., Garcia-Martin L.O., López J.L. Sánchez, 1992, Influence of seasonal environmental changes on the gamete production and biochemical composition of Crassostrea gigas (Thunberg) in suspended culture in El Grove, Galicia, Spain. J. Exp. Mar. Biol. Ecol. 155, 249-262.

Shpigel M., 1989, Gametogenesis of the European flat oyster (Ostrea edulis) and Pacific oyster (Crassostrea gigas) in warm water in Israel. Aquaculture 80, 343.

Sokal R.R., Rolhf F.J., 1969, Biometry, Freeman Press.

Ziegler A., Faber C., Mueller S., Bartolomaeus T., 2008, Systematic comparison and reconstruction of sea urchin (Echinoidea) internal anatomy: a novel approach using magnetic resonance imaging. BMC Biol. 6, 33. 